\title{
British Pakistani Muslim Women's Political Empowerment and Boundary Crossings: Case Studies
}

\author{
Dr Fazila Bhimji \\ University of Central Lancashire
}

\begin{abstract}
This paper traces the ways in which three Pakistani British Muslim women traverse a series of geographical and ideological spaces in their engagement with social justice issues and electoral politics. The women, all from the northern city of Rawalpindi in Pakistan, have been politically active in Manchester and Blackburn in northern England. Drawing upon in-depth interviews and several informal conversations conducted over a period of four years, I examine how these British Muslim women have resisted some of the constraints upon their lives - including those reproduced through negative media representations - through engagement with a series of spaces: national and regional spaces, geographies of home and family, gendered spaces, racialised spaces and public sites of resistance.
\end{abstract}

\begin{abstract}
British South Asian Muslim women's identities continue to be associated with veiling, forced marriages, honour killings and non-integrated lives within the dominant culture. This essay aims to contest some of these stereotypical assumptions. In doing so, the paper provides insights into varying expressions among racialised populations as well as contributing to scholarship on the configurations between space and racialised people.
\end{abstract}

British Pakistani Muslim Women's Political Empowerment and Boundary Crossings: Case Studies Since the Rushdie controversy ${ }^{1}$ in Britain in the late nineteen-eighties, Muslims have attained increased visibility within the British state and society. Muslims have been presented by the media in homogeneous and negative ways despite much diversity among this religious group. For example, in 2006, Jack Straw's comments concerning the full veiling (the niqab) by British Muslim women in his surgery in Blackburn led to weeks of debate in British newspapers, radio shows and prominent television news shows such as the BBC's Question Time. (http://news.bbc.co.uk/1/hi/programmes/ question_time/5410654.stm) (see also Beckett 2006). Representations of British Muslim women become increasingly narrowed as much of the discussions and debates in the media concentrated on their decisions about how to dress and make visible their religiosity.

Similarly, in early 2008, British Muslim women came into focus once again when the Archbishop of Canterbury commented on the consequences of introducing certain aspects of the Islamic Law (Sharia) in the UK. His comments were immediately equated with the previously discussed views of forced marriages, forced wearing of the veil, and honour killing, and even were echoed British broadsheet newspapers such as the Independent, which had on its front cover an image of a woman with a fully covered face, with only the eyes showing. Such limited representations of Muslim women in the media can only serve to reinforce discourses of exclusion rather than inclusion in British society as well as in the global context.

Such assumptions and preoccupations have since resulted in cultural, social, and political tensions between the wider society and Muslims living in Britain. Over time, such discourses of exclusion have far from dissipated, since the media continues to depict Muslims in monolithic terms; and Muslims are consequently perceived to be living parallel and constrained lives within the white dominant culture. Phillips (2004) argues that discourses of ethnic self-segregation have understated the diversity within the Muslim community and have continued to view ethnic clustering as a problem. Brown (2008), in turn, argues that the state understands Muslim women in Britain as inherently disempowered needing to be empowered through various government policies and strategies allowing them to work 
in wider society in proactively supporting the tackling violent extremism.

British South Asian Muslim women's own sense of empowerment, and their engagement in varying spaces, as this essay aims to illustrate, does not form part of the discourse about them; rather, they continue to be associated with veiling, forced marriages, and honour killings-living non-integrated lives within the dominant culture.

In the last decade, much writing has been devoted to contest the reification of British Muslim Asian women's identities - signalling multiple and/or contradictory notions of belonging, location, and cultural reference points. Brown (2006), in her study of British Muslim women, highlights the fact that British Muslim women's religious understandings of are not acquired in passive and de-contextualized ways; rather the young women make efforts to understand some of the rights, which Islam may provide them with within the context of living their lives as second generation Asian Muslims in Britain. The lives of young British Muslim women are inscribed by gender relations, social inequalities, and the wider societal context of racism (Dwyer 2000).

Scholars have also recognized the diasporic and cosmopolitan identities of British Muslim women. For example, Dwyer (1999) draws attention to complex understandings of the wearing of the veil elucidated by young British Muslim women who assert their rights both through wearing a hijab and wearing Westernized clothing. She suggests that by mixing two cultural codes these young women contest to some extent the traditional values of their parents and measure their own independence. Others have attended to the cosmopolitan identities of British Muslim Asian women (Bhimji 2008; Tarlo 2007). Tarlo examines the cosmopolitan features of veiling of three prominent Muslim women in London: the textile artist Rezia Wahid, the stand up comedian Shazia Mirza, and the councillor and advisor on Muslim affairs, Salma Yaqoob. She argues that their 'stylish' appearance has more to do with the influence of local and global forces than with inherited religious and cultural practices. Rather than viewing second and third generation Muslim women either as British or Asian or Muslim, with more travel opportunities and advancement in technology, it becomes important to understand women's identities and agency in a much more global and cosmopolitan context (Bhimji 2008; 2009). These women manifest simultaneously a sense of belonging towards their nation states as well as cosmopolitanism through travels to various countries including their families' country of origin.

The experience of Muslim women's assertion and agency within spaces of formal education has been discussed in depth. In examining the motivations for pursuing higher education among British South Asian Muslim women, Ahmad (2001) points out that 'agency' for the women she interviewed was a process of negotiation between traditional and Western norms with considerable overlaps. Similarly, Shain (2003) discusses assertions of agency and boundary crossing among British Muslim women in the context of schooling. In her research, Shain brings to the fore the ways in which Muslim young women resist inequalities, racism, sexism and social class within educational spatiality.

British Muslims' political identities have also received some attention. Scholarship has recognised the diverse ways of 'being' a political Muslim:

'...some prefer to keep their religion private, others work primarily through other identities and/ or organizations-approaching politics as socialists, Asians or Bangladeshis, for instance, and/or as British citizens, Welsh or Scottish nationals, Londoners or Liverpudlians' (Philips and Iqbal 2009: 171).

However, British South Asian Muslim women's engagement with politics has yet to be the focus of scholarly work despite the fact that British Muslim women are increasingly participating in both electoral politics as well as political activism. As Abbas (2009) states, four Muslim women were standing for election in parliament in the British General Election of May 2010. 
This essay, in tracing the ways in which British Pakistani Muslim women come to cross spaces while being politically active, contributes to the above mentioned discussions of their assertions of cultural, social, and political rights. I use the term 'politics' here in the way that the research participants understood it, which was participation in electoral politics as well as their engagement in social movements such as anti-war movements, anti-racist, and or anti-deportation movements, which in turn led to furthering their political awareness and political consciousness. More specifically, the study examines ways in which three British Pakistani Muslim women reflect on their engagement with social justice issues and participation in electoral politics, their various affiliations and collaborations and some of the challenges they encounter in the process. In doing so, the article contributes to further insights into political expressions among racialised populations and the ways in which these women experience, contest and negotiate a series of spaces in the course of their political engagements. Brah (1993) discusses how racialised South Asian women in Britain provide their own narrative about the labour market. She emphasises the importance of making distinctions between 'Muslim woman' as a category of discourse and Muslim women as concrete historical subjects with varying and diverse social and personal biographies and social orientations' (p. 443). By demonstrating the ways in which three British Pakistani Muslim women describe their subjective experiences with activism and electoral politics in varied spaces, this study aims to deconstruct the 'Muslim woman' as a reified category within wider British society. Many scholars have noted the varying configurations of space as dynamic, fluid, and mutually constitutive rather than static (Hopkins et. al. 2007; Nagar 2004; Mills 2007; Mohammed 2005). Following this definition, this article will demonstrate British Pakistani Muslim women's engagement with different types of spaces. It also aims to contest stereotypical and fixed assumptions that they are bounded in fixed and limited spaces, as well as furthering the scholarship on intersections between racialised populations and space. Although, some scholarship (Bhimji 2009, Lewis 2009, Mills 2009) has acknowledged the complex relationship between space and British Muslims, it has largely focused on specific spatial communities such as the mosque, fashion retail, and scouting groups. In this study, I explore a series of spaces such as mosques, familial spaces, social spaces, sartorial spaces and the varying ethnic and political spatiality that the three British Pakistani Muslim women experience. In doing so, I illustrate how racialised populations need not always be linked to a limited range of specific spaces, but rather are people who experience a wide array of spaces in dialectical and complex ways.

\section{Meeting the Women in Different Spaces}

I selected to interview the three Pakistani British Muslim women for a variety of reasons. One of the obvious reasons was my aim to continue to contest some of the dominant discourses surrounding British Muslim Asian women since the political activities of these women meant that they challenged the stereotypes. Secondly, all three of them were based in the northern England, a region which has been the subject of relatively few studies as much of the academic focus to date has been on London. Thirdly, the women varied in the ways in which they were engaged politically and held different opinions, thus further contesting essentialised perceptions of Muslim women. The interviews took place across a series of spaces which were important to the women's lives.

All three women I interviewed had their origins in northern Pakistan and were born in the UK. Even though they had similar backgrounds they differed from one another in several ways, such as in terms of their political leanings and religious expressions. They also differed in the extent to which they embraced their Pakistani and British identities. This diversity demonstrates the heterogeneity of British Pakistani Muslim women, even amongst those that have very similar backgrounds in terms of places of origin and within such a small sample.

Of the three women I met with, Farhana was the oldest - being in her early forties; Jahandra was 
in her mid thirties and Nasrin in her early thirties. Jahandra was married, and to a certain extent her marital status did affect her activism since she was married to a law officer who initially had a different political vision. The other two women were single. All three had postgraduate degrees, were working in professional jobs and were daughters of first generation migrants to the UK. Farhana, Nasrin and Jahandra shared similar class backgrounds, since all three of them grew up in middle class neighbourhoods in Manchester.

Jahandra explained that she spent her childhood years in a predominantly white middle class neighbourhood and went to a school where she was the only student in the class with an South Asian background. Although Jahandra's formative years differed from those of Farhana and Nasrin she shared a their political outlook. Jahandra stated that she acquired political consciousness during her University years.

I met two of the three women during the course of their activism. I first met Nasrin, as a woman in her late twenties, in the spring of 2004 upon encountering an announcement in the weekly Manchester City magazine about a lecture she was giving entitled 'Why Socialists are not in Conflict with Muslims'. I went to her lecture during which she addressed a group of mainly White males and females, some of whom looked like students, though others were older. I later discovered that many of them belonged to the British left alternative party the Socialist Workers Party (SWP). Nasrin's lecture was on the French government's ban on the wearing of headscarves by Muslim women in state schools.

Following the lecture, I introduced myself to Nasrin, and told her about my research. She agreed to meet up with me once she had returned from a visit to Jordan. Over the course of the next four years, I met Nasrin in varying spaces and contexts. I attended some local anti-war demonstrations with her held in Manchester and we also met at meetings concerning the Manchester campaign against Guantanamo Bay. On occasions we met socially to watch alternative films or for lunch or dinner. More recently, in 2008, I helped her campaign when she stood as a candidate for the Respect party, which grew out of the anti-war movement. Thus from the very outset, she provided evidenceto support my view, that all British Muslim women did not necessarily lead parallel lives but rather engaged with people outside their own ethnic clusters and geographies. I also noticed that over the years in talking to her as well as following her political activism, she was perhaps one of the few Muslim women I had encountered who simultaneously embodied SWP and Muslim identities. In the past she had encountered some differences with activists from the Asian Youth Movement (AYM) who had a more secular outlook and were also to a certain extent critical of the SWP's political agenda since they felt that the party focused primarily on class politics and did not engage with the politics of race. Despite these differences, Nasrin did continue to meet with the former AYM members. For example, in the year 2004, some members of the AYM launched a campaign to free prisoners held at Guantanamo bay and Nasrin attended a number of these meetings - reflecting her continued engagement with varying spaces of activism.

The second participant, Farhana, was extremely well travelled and seemed to regularly cross ethnic and social boundaries over the course of her political activism. I found that Farhana was quite critical of the SWP's political agenda. However, she did respect their activism but told me that she could not absolutely identify with them. I met Farhana when she was in her early forties through the meetings of the Manchester campaign against Guantanamo bay. However, because Farhana frequently travelled to places such as India, the US and Europe, I saw her less frequently than I saw Nasrin. Between 2004 and 2008. I met with her at anti-war demonstrations, various political events, and social engagements. Fahana also moved to London and then to Birmingham during this time period. Farhana was an extremely articulate woman who spoke her mind in a candid fashion.

I met the third participant, Jahandra through Nasrin who told me that Jahandra had been 
particularly active in the anti-war movement in Blackburn, but had recently moved to Nottingham. I was particularly interested in meeting somebody from Blackburn since the US Secretary of State, Condoleeza Rice, had put it on the global map after visting it in 2006, following an invite from the then Labour Cabinet member and local MP, Jack Straw - a visit which induced protests. Following Miss Rice's visit to Blackburn, the city's Muslim residents continued to receive much attention as Jack Straw also made statements concerning his discomfort with veiling practices amongst British Muslim women attending his surgery. Hence, when Nasrin suggested that I meet with Jahandra in Nottingham, it seemed a good opportunity to discuss these events and the subsequent debates with someone who had witnessed them first-hand.

All three women identified themselves as practising Muslims. Of the three, two of them wore headscarves on a regular basis. I had never seen Farhana with a head scarf. Jahandra said she had chosen to wear the headscarf while she was working and living in Blackburn but had ceased to do so when she moved back to Nottingham since she realised that she was not closely attending to the other tenets of Islam and did not wish to cover her head simply for the sake of doing so. Nasrin almost always dressed relatively simply with hardly any make-up usually wearing a long skirt, a blouse, and a plain headscarf which matched her skirt. Because of this simplicity of dress, Nasrin's sartorial choices conveyed to me an SWP/Islamic identity since most members of the SWP dressed in similar ways. Farhana was much more fashion conscious and she tended to dress more ostentatiously with jewellery and make-up, alternating between Pakistani and British fashion styles. Jahandra dressed in a much more conservative and professional manner, usually wearing trousers or long skirts. The differing styles were significant because they conveyed each of these women's engagements and relationships with diverse spatialities.

The women I met with conveyed their Muslim identities in numerous ways. For example, during the Islamic month of Ramadan, theyall told me that they spent extended hours at the mosque and that at work they made special arrangements to pray. One of the women wore the Pakistani dress Shalwar Kameez regularly to work during the month of Ramadan, rather than adhering to the British fashion - a gesture which she understood as a way of being expressly Muslim. Although, the three women conveyed differing ways of practicing Islam with some of them becoming more overt in their practice during certain months of the Islamic calendar, all three of them understood their religiosity as a holistic way of being rather than simply following religious tenets.

I use the term British Pakistani Muslims to refer to the women I met with as this is one of the ways in which the women I spoke with self-identified themselves. They also individually self-identified as British Asians, British Pakistanis, British Muslims, Muslim women, Mancunian, and Black. I too, self-identify in a number of ways: as a lecturer researching British Muslim women's identities, born in Karachi, Pakistan, and as someone who has lived in Los Angeles for a number of years prior to relocating to the UK for work.

The interviewees were quite willing to speak to me, especially since I had known two of the women over the course of several years.

My secular views did not prove to be a hindrance. The fact that we all felt dissatisfaction with the Iraq War provided common ground with all the women. Being of Pakistani origin also helped connect me with the research participants.

I interviewed Nasrin in a space which was politically quite significant to her; a Palestinian café, where several political groups often met. This was facilitated by the staff as they shared the political views and beliefs of the groups such as the SWP, Stop the War Coalition (STWC), Palestinian Solidarity Group, Respect Party, as well as some student groups from the nearby campus of Manchester 
University. I met Farhana in her apartment located in a fairly mixed neighbourhood of Birmingham and thus interviewed her in her own space. I met with Jahandra at a local tea room located outside the Nottingham train station. Thus, even the spaces where I conducted the interviews varied and by no means could be envisioned as segregated spaces in terms of gender, religion, class or ethnicity. The women with whom I had extended conversations proved to be extremely articulate as well as self-reflective, taking great care to answer my questions. Much of the time I let them do the speaking, allowing them to talk about what they considered important and significant to their political lives.

\section{Geographies of Homes and Family}

The spaces which facilitated Muslim women's political awareness tended to vary. Jahandra and Farhana highlighted that their familial and domestic spaces played a significant role in their politicisation process. Farhana mentioned to me during the interview that she considered herself to be quite fortunate to have parents who encouraged her political activism. Her mother did not have any experience in politics in her home country of Pakistan, but gained political consciousness upon moving to England and in turn helped politicise her:

'I got politicised very early on. Well my father was an intellectual creature, but my mother was involved in the community as women often do. And she knew lots of women in the community and they needed help this that and the other. And she got my dad to help them out. Mostly through her work in the refuge. Mostly voluntary. She was working there as an advocate. She was giving them a lot of emotional support and counselling and through her connections with the refuge. I started to work there as a nursery nurse's assistant in all the summer holidays and Christmas and Easter holidays. That is where I began my politicisation. I saw all the gender politics and domestic violence. I would be often accompanying my mum to demonstrations anything to do with domestic violence or anti-immigrant laws. Mostly because of my mother because I was 14 that I started working in the nursery nurse in the refuge. I graduated to working as an advocate for the women.... I remember going to anti-Hudood law demos that Zia-ul-Haq brought to Pakistan that were very anti-women. My mum came as well and there we were with our loud hailers and coaches coming up to London. (10-7-2008)'

Thus, it was Farhana's mother who paved the way for her political development through her work with women suffering domestic violence.

She describes her father as an 'intellectual creature' who was not always involved with the community, and was encouraged to get involved in the refuge by her mother, as she was. This is significant, since her account depicts the crucial role of gender as well as family in her politicisation process. Mohanty (1991) notes that 'third world women' are often viewed within Western society as 'traditional' and victims and their agency remains unexplored and overlooked. However, in this context, Farhana's mother plays a significantly active role within the Pakistani community in Manchester as well as the political socialisation of her daughter. Moreover, Farhana's varied roles working in the refuge further contributes to the discussion of the extent and types of spaces that lead to politicisation process of Muslim women. In this case, it was family, gender and the women's refuge that helped Farhana gain political consciousness.

Furthermore, it is evident from the extract above that Farhana makes distinctions between political activism for social change and voluntary work - she mentions that her mother was doing mainly 'voluntary work' but became politicised by virtue of her experience in that particular space. Cornelius (1998) discusses some of the strategies that can be employed whilst working in education for socializing young people to social activism. However, working for a refuge is outside the bounds of formal education through which women may develop political consciousness. Thus, it can be argued that the family, as well as some voluntary activity, that can provide an alternative arena for socialising young people to political activism. 
Similarly, Jahandra attributes her political awareness to her family and the older generation who she claims were far more politically conscious than her younger generation. In particular she citedher father's political consciousness as a significant influence on her politics:

'And I would listen to my dad and linger around when my dad would have meetings. I remember when Zulfiqar Bhutto was hung and there were huge demonstrations across the nation and I remember being involved in those demonstrations with him and being in front of these lines and shouting out slogans. I was five or six at the time though. $(5-6-2008)^{\prime}$

Werbner (2002) elucidates how first generation Pakistani immigrants often continued their involvement in Pakistani politics even though they lived in Britain. However, there is little information on the ways in which the first generation Pakistani diaspora's continued links and interests in Pakistani politics impacted their children's political consciousness. In the case of these two women, such continued interest in the politics of their home country certainly contributed to their level of political awareness and consciousness.

\section{Spaces of Resistance}

Family and home were not the sole space where women gained knowledge about politics. For Nasrin, who ran as a Respect party candidate for three years, it was the anti-war demonstrations along with her family that helped open the door of politics. She vividly described to me the first anti-war demonstration she went to in Hyde Park in London:

I got politicised when I was living in London when I went to this anti-war demo before the big one. It wasn't very massive but it was big enough. I remember my sister telling me about it and saying that it would be really, really big and I was yeah right and I thought it was something that the mosque was doing. So I did end up going with her to Hyde Park with her friends and being completely amazed. And my family ended up coming to this demo. It was kind of weird. It was different also because it was all age groups. I remember just walking up and down the demo and people handing out different things, all kinds of leaflets about different events that you never thought about. At one point we were walking up and down and we knew that our dad would be at the demo but we did not know on which coach and he did not have a mobile and we ran into him and saw him handing out leaflets. We were "Dad what are you doing?" And he was like, "somebody just handed them out to me on the coach" and he was "I am doing my bit." Really it was a turning point. But I never expected it to go on for so long. (1-6-2008).

Thus for Nasrin, it was a combination of different factors that led her to the development of her political outlook. First it was the activism against the war in Iraq, followed by her sister's encouragement to go to the particular demonstration, and further and perhaps more significantly, it was the presence of her family members within this public space which was relatively new for her. The above account also suggests Nasrin's willingness and excitement at participating in a sphere that was perhaps not entirely familiar to her and shows that she was not confined to her ethnic grouping, since the anti-war demonstrations included a wide array of people from diverse backgrounds.

Whereas dominant discourses in Britain and in Europe would situate Muslim women in the domestic sphere, it is evident from this account that Nasrin manages to blur the boundaries between the public and private, which reflects the problematic nature of this distinction as noted by various feminist theorists (Fraser 1991, Massey 1994; Silvey 2004). By stating that 'she walked up and down Hyde Park' Nasrin conveys a sense of willingness to participate in the public sphere. However, she also highlights the fact that she saw her father handing out leaflets. Perhaps she felt reassured to see her father especially to participate in the demonstration. This is significant as it further highlights how the public and private sphere can be merged, and also how the blurring of such divisions can become a source of inspiration for women. 
It should also be noted that although several spheres contributed to the formation of these women's political identities, the women in turn also changed the spheres they participated in by virtue of their politics. Just as Nasrin's political impetus grew through participating in demonstrations organised by the Stop the War Coalition and the Social Workers Party, Farhana became politicised by being active in movements such as the Asian Youth Movement (AYM), Farhana points out:

'I did not want to align myself to any specific party or movement. Although, I definitely did align myself to the Asian Youth Movement that was the only movement that ticked all the boxes. I was formally a part of that group. The criteria that I would be willing to label myself with because it was about Asians, it was about youth, it was about anti-racism, anti-imperialist. Because it was a new movement it did not have any history associated with it, which meant that I didn't feel that I was being labelled. I felt that I was being part of a new creative movement -innovative and maverick like. In many ways that group was predominantly based in the North in the North West and surrounding cities. I felt comfortable with that group of people and felt had many things in common with themlots of identification factors: they were the same age, they were all British Asians, they were Muslims, Sikhs, Hindus and whatever you know and I think they came the closest with me identifying with them and them identifying with me, which was why I felt okay about being part of that group. Other than that I have not felt comfortable with the politics of any particular group either the Labour Party or the Socialist Party group or the Communist Party. There were always different parts I relate to but never as an entirety. Because of the racism because I as a Black person in this country I never felt enough of a part of SWP. I felt that they were predominantly White. (10-7-2008).'

The AYM for Farhana embodied what she valued by being both anti-racist and anti-imperialist. Furthermore, she was also able to relate to the group because it reflected her additional identities of being Asian and young. However, what is significant is that she does not necessarily remain rooted in her religious identity but rather expresses and articulates varying ideological spheres such as being anti-racist, anti-war, and class conscious through her political activism. It is additionally significant, that among contemporary political parties and movements on the left Farhana is unable to feel comfortable with any of them as she points out that 'because I as a Black person in this country never felt enough of SWP. I felt that they were predominantly White.' Furthermore the SWP has much concentrated on a class-based politics rather than focusing on gender, race or religion. Hence it is understandable that Farhana who self identifies herself as a Black Muslim Asian woman could not completely share the political visions of the SWP. Amos and Pamar (1984) have commented that 'as Black women we have to look at our history and at our experiences at the hands of a racist British state.' Farhana's quote reinforces this point very well, since she defines for herself her own trajectory of political activism based on her own experiences and intersectionalities in terms of race, gender, class, space, and religion

Scholars of new social movement theory (Polleta and Jasper 2001; Touraine 1985; Melucci 1985) have pointed out that activism around issues such as peace, nuclear energy, homosexuality, and feminism cannot simply be explained in terms of class location. These three politicised British Muslim women with were no exception to this issue. They were middle class Muslim women of South Asian origin whose politics embodied multiple ideological spheres. Secor (2001) focuses on how lower and lower middle-class women engage with Islamist politics in Turkey. However, in Britain, Muslim women are not necessarily bound to religious politics but may engage in a more cosmopolitan form of politics, which may encompass broader political goals. Hence, when we think of what crossing boundaries, empowerment, and politics mean for British Muslim women, it does not necessarily translate into crossing from one group and becoming part of another group but rather needs to be conceptualized in terms of these women's search for visionary political spaces which encompass a wide range of values and beliefs. 
For Farhana, the AYM was such a site because it transgressed multiple spheres but was primarily a site of resistance for young Asian people. As several social geographers (Massey 1994; Mohammad 2005; Secor 2005) have noted, spaces need to be understood in dialectical ways rather than as disembodied entities. Thus, by participating in different geographical and ideological political spaces, these Britishborn, second generation, Pakistani, Muslim women also cast their own influence in these spheres by transforming them from sites which had mainly been dominated by British White middle class liberals to ones that were feminine, Muslim, South Asian British, and politicised at the same time.

\section{Negotiating Gendered Spaces of the Mosque}

The question of gender became most significant for the three women when they needed to interact with orthodox Muslim male religious leaders and had to find ways to gain their respect in order to move forward with their political goals. For example, Nasrin who was relatively newer to politics than Farhana and Jahandra discovered that it was much easier, in certain instances, working with people outside her own ethnic background than to work with male Muslim figureheads in her own religious and ethnic community. She commented that on several occasions that as a candidate for the alternative party Respect she found it necessary to speak with Imams and gain their support. In one instance, she was denied out the right to address a male dominated audience in the mosque by the imams. However she refused to be defeated and negotiated the situation by involving her father in the process:

'And I spoke to my dad and my dad said: "It's nothing to do with me. I don't know these people." "Dad yes you do. You have to go and find out why they won't let me on. It's not like I need different chairs. I can sit on the same chairs they all sit on." He came back to me and said that it's because there is going to be no women there.

So they are not going to have me there because there are going to be no women there. And I was "why are there no women there? Is it because it is a male only meeting?" And he was, "No, no, women don't come." And I was like, "Well I am going." I asked him "Are you coming?" "Do I have to?" I was, "How would you feel if I am going to be on the platform and there is going to be no woman there?" And he was, "Do you have to go?" And I was, "Yes I have to." "Well if you dress respectfully than I'll come along." As if to say that, "You are not going to show me up are you?"

And yeah I was the only female. I mean I sat back and contributed. It wasn't a massively big meeting compared to some of the Stop the War Meeting. At the end of the meeting I spoke to one of the imams who was one of the oldest imams in Manchester. He is the first imam who knows my dad really well. And he was, "Nasrin it is good what you are doing because I don't want to do it." I think that was a shock and my dad was, "You know him?" And I was, "but I know him." So that was good (1-6-2008).'

Scholars of social movement theory have commented on alliance-building and coalitions among multiple and different movements in order to advance their agendas such as Roth (2003), but in this instance the British Pakistani Muslim women had to form links within their own ethnic and religious communities and in that process they had to struggle along gender lines. It is also significant, that Nasrin finds a way to bridge the gap between herself and the Imams at the mosque through reverting to her own familial space by seeking help from her father. In this way, further evidence is shown of the intersection of various spheres such as the religious, the familial and the political, since Nasrin addresses the attendees of the mosque with a political motive with her father present. However, what is interesting here is that she manages to gain approval of a well respected imam who acknowledges her political endeavours. Hence, not only does she manage to blur the boundaries between these spaces but she is highly successful in negotiating these multiple and at times discrete spaces.

Much of the dominant discourse in the media would not necessarily make such links between such 
varying spaces, but a closer examination of the political lives of some of these women show that not only do they manage to transgress varying spaces but they also manage to find links and connections between multiple geographical and ideological spheres. Similarly, Jahandra discovered ways to speak to the male Muftis (religious scholars), particularly when she was involved with the Stop the War Coalition in contesting Condoleeza Rice's visit to the mosque in Blackburn. She explained that she discovered when talking 'head-to-head' with them (Islamic religious leaders) that they actually listened to her and she gained respect from them:

'I've been in touch with a number of them and they have shown me the same level of respect and have been absolutely fantastic. I now work with the Islamic foundation and they have been great. There is that element of judgement among some scholars of the wider Muslim community but you know you have to just stand up and say that I want to talk to you. (5-6-2008).'

Jahandra continued to form alliances and links with religious leaders within the Muslim community after she realised that the best way to negotiate with them was to insist on speaking to them. In this way, much like Nasrin, she bridged the boundaries between political and religious spheres.

\section{Contesting Racialised Spaces}

Whereas Nasrin and Jahandra spoke about the challenges they had to confront in order to gain support from male religious leaders within their own community, Farhana told me how she had to contend with issues of racism as a Pakistani British Muslim woman. She said that her outspoken candid style was often viewed in negative ways, but she fought on believing that members of immigrant communities are inherently fighters:

'I am a fighter. A lot of Black people are. We are warriors. A lot of people who come to this country we've got to warrior our way through. We get knocked about. We fight sometimes. We lick our wounds sometimes. We do what we can do to survive. We do what we can to hang on to our integrity and our cultural base. And I think by our very nature of being immigrants we are fighters. You gotta be a bit of a fighter to leave everything you know, get on a plane and go to a completely different country where you don't speak the language and you are not surrounded by your own people. That is somebody who is adventurous. You have to be a bit of a fighter to go to a different country to improve your own life economically or educationally. Those are the things that gave me strength. But I was very fortunate that I had very strong parents. They gave me confidence and self esteem. They gave me political backing, personal backing. (10-7-2008).'

Farhana's account shows that she was affected by wider societies' definitions of racial identities, but then, much like Nasrin and Jarhandra, found strength within herself as well as from her parents to continue with her political and daily battles. More significant, is that these women find ways to contest difficult situations both within and outside their religious and ethnic communities within themselves and their own familial spaces. Accounts such as those of Farhana's also contest discourses which position Asian women's first generation immigrant families as rigid and traditionbound since, at least in these three instances, familial spaces helped form their political identities as well as helping the women overcome challenging issues around race and gender.

British Muslim women are generally depicted in the British media in homogenous and narrow ways,. To overcome this requires a great deal of determination. Farhana, in her accounts, does not always explicitly state that, as a British Pakistani Muslim woman, she experiences racism, but she does imply that there is always a struggle in terms of battling dominant ideologies concerning her race, gender, politics, religion, and ethnicity. 


\section{Crossing/Sharing National Spaces}

In the course of their political activism the women crossed boundaries, encountering cultural, national, and political zones that they might not have had experienced were they not in these political spaces. Nasrin spoke about her experience canvassing as a Respect candidate in the Bangladeshi section of the town, where she actually found a great deal of support:

'There is a predominantly Bengali community in the ward. There is the language barrier. And they are open to stuff. It would have helped if I had spoken Bengali. When you talked about the housing issue and the lack of schools it all went down really well. It wasn't just the war. I think it also helped that we got the Bengali council elected nationally and they were on Bangla TV helped. So when you are knocking on doors at least they are aware of who you are. And the Bangladeshies seem to live in the worst areas of the ward and the Pakistani community is better off and so they are not open to your politics. So there is that kind of support where class issues play a role. We had a lot support from women who lived on the council estates and women who worked on the group and they were completely open to us more so than the Pakistani community. I think that's because of the politicsbecause they don't see us being closely aligned to the Labour government. I think it does come to a class issue. (1-6-2008).'

In the course of canvassing Nasrin had the opportunity to meet the most disenfranchised group within the South Asian community and managed to cross not only national, ethnic, and cultural boundaries but also class boundaries. In the above excerpt, Nasrin modestly describes the support she received from the Bangladeshi community. However, I noted that Nasrin put increased efforts into canvassing in the Bangladeshi section of her ward. I observed her personally leaflet from door-to-door, making house visits, and engaging in informal conversations with the Bangladeshi people, if they happened to be on the street or working in their front yards. In some sense such levels of boundary-crossings can be viewed as a cosmopolitan experience when one thinks about cosmopolitanism in the broadest sense which includes ways of viewing life and rationalities such as the otherness of others (Beck 2000).

Thus even though Nasrin in her account locates her engagement with the Bangladeshi community in terms of class, it remains significant that over the course of the campaign she successfully interacted with other ethnic minority groups with other national heritages and languages who lived in a section of Rusholme where there was a higher concentration of Bangladeshis than Pakistanis. Furthermore, she states that the Respect Party helped the community gain political representation-thus showing her understanding that minority groups need to overcome structural and racial barriers.

\section{Concluding Comments}

This piece demonstrated that the women's political participation led them to cross boundaries and overcome several challenges such as patriarchy, racism, and political battles. Central to this is that they displayed the extent to which they struggled towards empowerment for themselves and for others. In several instances, they had to cross spaces within their own religious and ethnic community in interaction with orthodox and rigid-minded religious clerics and in other cases they had to negotiate with predominantly White middle class liberals. Their political activism additionally led them to experiences spaces other than their own - for example, meeting with working class Bangladeshis, politicians, as well as predominantly White middle-class members of the Socialist Workers Party. However, it is important to consider the fact that in the course of their activism the women crossed spaces that provided them with opportunities to meet people from other nation-states such and interact with White British individuals from the Left. In this regard, we need to question these types of crossings mean? What promises do they hold for the future? Will the opportunity to engage with such diverse spaces be maintained and expanded or limited for these women? Furthermore, to what degree will their small successes and political leaps be recognised by others outside of their existing 
space. In this regard, one can look at Salma Yaqoob², the vice chairperson of Respect and currently a city councillor in Birmingham whose political career started out through her activism. Yet it can be argued such instances of success are few and far between. However, British Muslim women, or for that matter British Pakistani Muslims, who are on the margins cannot always shoulder this responsibility. The media and wider society need to recognise that many British Muslim women's geographies may be more expansive and complex where religiosity, politics, familial space, race, class, and gender come to intersect. No doubt the British media and to a certain extent the American media on the left did give a fair amount of attention to Salma Yaqoob when she was elected the councillor of Birmingham, however, there remains a number of Muslims who are striving for political change and recognition, and such efforts, however small, should also be acknowledged.

\section{References}

Abbas, T. (2009). After $7 / 7^{\prime}$ : challenging the dominant hegemony, in: Phillips, Richard. ed. (2009), pp. 252-262.

Amos, V. and Parmar, P. (1984). Challenging Imperial Feminism. Feminist Review, 17, 3-19.

Ahmad, F. (2001). Modern Traditions? British Muslim Women and Academic Achievement. Gender and Education, 13(2), pp. 137-152.

Aitchison, C. , Hopkins, P. E. and Kwan, M. P., eds. (2007) Geographies of Muslim Identities: Diaspora, Gender, and Belonging. Aldershot and Burlington, VT: Ashgate.

Beck, B. (2002). The cosmopolitan society and its enemies. Theory, Culture, and Society, 19(1-2), pp. 17-44.

Beckett, T. (December 29, 2006). British Muslim and the Media, Comment Section. Guardian.

Bhimji, F. (2008). Cosmopolitan belonging and diaspora: second-generation British Muslim women travelling to South Asia. Citizenship Studies, 12(4), pp. 413-427.

Bhimji, F. (2009). Identities and Agency in Religious Spheres: British Muslim Women's Experience. Gender, Place, and Culture, 16(4), pp. 365-380.

Brah, A. K. (1996). Cartographies of diaspora: contesting identities. London: Routledge.

Brown, K. (2006). Realizing Muslim women's rights: The role of Islamic identity among British Muslim women. Women's Studies International, 4(29), pp. 417-430.

Brown, K. (17th April, 2008). Gender, Security and Citizenship: the gendered politics in and out of Britain's Muslim communities. Conference Paper presented at Framing Muslims Conference at SOAS, London.

Bunting, M. (October 13, 2006). Straw's Storm of Prejudice. Guardian Weekly.

Calhoun, Craig., ed. (1992). Habermas and the Public Sphere: Studies in Contemporary German Social Thought. MIT Press: Cambridge, MA.

Cornelius, D. (1998). Walking the Walk: Socializing Students to Social Activism. Teaching Sociology, 
26(3), pp. 190-197.

Dale, A., Shaheen, N., Karla, V. and Fieldhouse, E. (2002). Routes in Education and Employment for Young Pakistanis and Bangladeshi Women in the U.K. Ethnic and Racial Studies, 25(6), pp. 942:968.

Dwyer, C. (1999). Veiled Meanings:Young British Muslim women and the negotiation of differences, 6(1), pp. 5-26.

Falah, G. and Nagel, C., eds. (2005), Geographies of Muslim Women. New York: The Guilford Press.

Fraser, N. (1992). Rethinking the Public Sphere: A Contribution to the Critique of Actually Existing Democracy. in: Calhoun, Craig., ed. (1992), pp. 109-142.

Hopkins, P. E., Kwan, M. and Aitchison, C. C. (2007). Introduction: Geographies of Muslim Identities in: Aitchison, C., Hopkins, P., Kwan, M. eds. (2007).

Lewis, R. (2009). Veiles and sales: Muslims and the spaces of post-colonial fashion retail, in Phillips, Richard. ed. (2009), pp. 69-84.

Massey, D. (1994). Space, Place and Gender. Oxford: Polity Press.

Melucci, A. (1985). The Symbolic Challenge of Contemporary Movements. Social Research, 52, pp. 789-816.

Mills, A. (2007). Gender and Mahalle (Neighborhood) Space in Istanbul. Gender, Place, and Culture, 14(3), pp. 335-354.

Mills, S. (2009). Citizenship and faith: Muslim scout groups. In Richard Phillips, ed. (2009), pp. 85-103.

Mohanty, C.T., Russo, Ann and Torres, Lourdes. (1991). Third World Women and the Politics of Feminism. Indiana: Indiana University Press.

Mohammed, R. (2005). Negotiating Spaces of the Home, the Education System and the Labour Market: The Case of Young Working Class, British Pakistani Muslim Women. In: Falah, G. and Nagel, C., eds. (2005), pp. 178-200.

Nagar, R. (1997). Communal Places and the Politics of Multiple Identities: the Case of Tanzanian Asians. Cultural Geographies, 4(3), pp. 3-26.

Phillips, D. (2006). Parallel lives? Challenging discourses of British Muslim self-segregation, Environment and Planning. Society and Space, 24(1), pp. 25-40.

Phillips, R. and Iqbal, J. Muslims and the anti-war movements. In: Phillips, Richarded. (2009), pp.163178.

Phillips, Richard. ed. (2009), Muslim Space of Hope: Geographies of possibility in Britain and the West. London and New York: Zed books.

Polletta, F. and Jasper, James, M. (2001). Collective Identity and Social Movements. Annual Review of Sociology, 27, pp. 283-305. 
Ramammurthy, A. (2006). The politics of Britain's Asian Youth Movements. Race and Class, 48(2), pp. 38-6o.

Roth, S. (2003). Building Movement Bridges: The Coalition of Labour Union Women. Westport, CT:Praeger.

Secor, A. J. (2005). Toward a Feminist Counter-geopolitics: Gender, Space and Islamist Politics in Istanbul. Space and Polity, 5(3), pp. 191-211.

Secor, A. J. (2005). Islamism, Democracy, and the Political Production of the Headscarf Issue in Turkey. In: Falah, G. and Nagel, C., eds. (2005), pp. 203-225.

Shain, F. (2003). The Schooling and Identity of Asian Girls. (Stoke on Trent:

Trentham Books.

Silvey, R. (2004). Power, difference and mobility: feminist advances in migration studies. Progress in Human Geography, 28(4), pp. 490-506.

Touraine, A. (1985). An Introduction to the studying of Social Movements. Social Research, 52, pp. 749-87. 